\title{
Helmut KallmanN: InSPIRATION, Guide AND Friend
}

\author{
BY JOAN COLQUHOUN MCGORMAN
}

It was an honour for me to know and work with Dr. Helmut Kallmann at the National Library of Canada (NLC).

When I began my career as a music librarian at the NLC in 1978 Dr. Kallmann encouraged me to continue to be a musician as well as a librarian. He invited me to his home to play my cello with him at the piano. A few times we also played piano trios. He loved to play chamber music and was so knowledgeable about it!

In 1981 Dr. Kallmann organized an exhibition celebrating the centennial of the birth of Leo Smith, a Toronto composer and teacher with whom he had studied at the University of Toronto. He also planned a concert of Smith's music and asked me to perform several of the pieces for cello and piano. We enjoyed practicing them together, although Elaine Keillor performed with me at the Leo Smith Memorial concert on November 26, 1981, in the NLC auditorium.

In 1982 Dr. Kallmann was asked to speak at the International Association of Music Libraries (IAML) conference about the Encyclopedia of Music in Canada, which had been published the previous year. (Although Dr. Kallmann had been the Canadian representative to IAML even before there was a national branch and had been involved with RISM and other IAML projects, he did not attend IAML conferences regularly.) I was very pleased that we were scheduled to travel on the same flights to the conference in Brussels, and Dr. Kallmann was a very congenial companion on the long journey. During the flight he showed me a Baedeker Guide to Belgium, 1903 edition, which he had purchased in a used bookshop. After landing in Brussels we took the train into the centre of the city. Using a map in the Baedeker, Dr. Kallmann guided us to our hotel a few blocks from the station. Later in the day he used the same antique Baedeker to guide us on our walk to the registration and the IAML opening reception. He knew that the streets, train station, parks, hotel and historic buildings we saw in Brussels in 1982 were well documented in the 1903 guide book. This experience emphasized to me how well he understood and valued history.

Dr. Kallmann and I were scheduled to travel to IAML together for a second time in 1985. I was certainly looking forward to having his companionship again. It would have been a particularly poignant journey for him to Berlin, the city of his birth. Unfortunately, he had to cancel his plans to attend IAML that year due to his wife's illness.

I am very glad that Dr. Kallmann encouraged me to be involved with the Canadian Association of Music Libraries (CAML) and IAML. He was a great inspiration to me as a music librarian, and in life. I was also very fortunate to have been able to renew my friendship with him after my return to Ottawa in 2007 and to see him frequently in his last few years. Our conversations often included the ongoing work of CAML and IAML. Since Dr. Kallmann had been very involved with planning the first IAML conference in Canada in 1975, he was especially pleased to know about the plans for the 2012 IAML conference in Montreal.

JOAN COLQUHOUN MCGORMAN was a music librarian at the National Library of Canada from 1978 to 1988. After beginning as a music cataloguer she was Head of Music Cataloguing, 19811986, then Head of the Recorded Sound Collection, 1986-1988. She served on the CAML Board from 1981 to 1988 and was President of CAML from 1985 to 1987. 